\title{
Rib fracture in Prognathodon saturator (Mosasauridae, Late Cretaceous)
}

\author{
A.S. Schulp ${ }^{1,2 \star}$, G.H.I.M. Walenkamp ${ }^{3}$, P.A.M. Hofman ${ }^{3}$, \\ B.M. Rothschild ${ }^{4,5} \&$ J.W.M. Jagt ${ }^{1}$
}

1 Natuurhistorisch Museum Maastricht, De Bosquetplein 6, NL-6211 KJ Maastricht, The Netherlands

2 Faculty of Earth and Life Sciences, Vrije Universiteit Amsterdam

3 Academisch Ziekenhuis Maastricht, PO Box 5800, NL-6202 AZ Maastricht, The Netherlands

4 Arthritis Center of Northeast Ohio, 5500 Market Street, Suite 199, Youngstown, Ohio 44512, USA

5 Northeast Ohio Universities College of Medicine, Carnegie Museum of Natural History, Pittsburgh, and Faculty of Bio-medical Engineering, University of Akron, USA

* Corresponding author: Anne Schulp; e-mail: anne.schulp@maastricht.nl

Manuscript received: April 2004; accepted: October 2004

\begin{abstract}
Two unusual bumps occur on the internal surface of a rib of the marine reptile Prognathodon saturator from the Upper Cretaceous (Maastrichtian) of Maastricht, The Netherlands. These bumps are interpreted as stress fractures, possibly related to agonistic behaviour.
\end{abstract}

Keywords: Cretaceous, Mosasaurs, The Netherlands, pathology, Prognathodon, stress fracture

\section{Introduction}

During the Late Cretaceous, mosasaurs constituted a large, successful and diversified group of marine predators (e.g. Bell, 1997). These squamates, closely related to snakes and monitor lizards, went extinct at the end of the Cretaceous, 65,4 million years ago.

Here we describe and discuss an unusual injury in the large mosasaur Prognathodon saturator Dortangs et al., 2002, which we interpret as a stress fracture. The appearance of this particular injury is unlike any other bone fracture we have seen previously in mosasaurs.

Pathologies in mosasaurs were recognised as early as the 1860s (Mudge, 1878), and various diseases have been recognised in mosasaurs ever since, including infectious spondylitis (Gaudry, 1890), avascular necrosis (Rothschild \& L.D. Martin, 1987), neoplasia (Rothschild \& L.D. Martin, 1993), ligamentous ossification of tail vertebrae due to physical stress (Mulder,
2001), and a plethora of bone fractures, bite marks and other traumas (e.g. L.D. Martin \& Rothschild, 1989; J.E. Martin \& Bell, 1995) which all helped to establish the idea that mosasaurs practised a rather 'rough' lifestyle (as suggested already by Williston, 1914). Compelling evidence of aggressive intraspecific competition in Mosasaurus conodon was reported by Bell \& J.E. Martin (1995).

\section{Material}

The material we describe here consists of a disarticulated part of a rib, broken into two pieces during discovery. Both fragments form part of lot NHMM 1998141 (collection of Natuurhistorisch Museum Maastricht, The Netherlands), the holotype of the large mosasaur species, Prognathodon saturator (Dortangs et al., 2002). The specimen comes from the upper Lanaye Member (Gulpen Formation, Late 


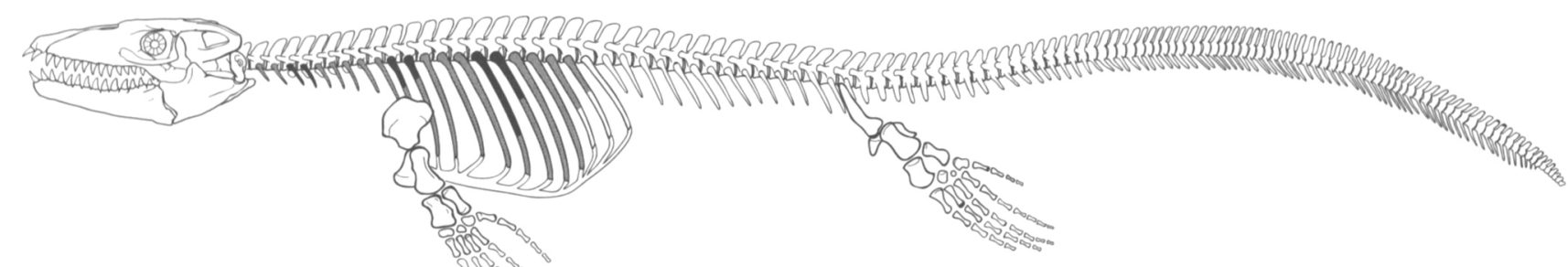

Fig. 1. Prognathodon saturator in left lateral view and rib cage in right lateral view. Ribs preserved in articulation in black; rib positions which are unlikely to have accommodated NHMM 1998141-44 because of reconstructed size or curvature are filled in grey. Reconstruction by Rogier Trompert Medical Art.

Maastrichtian) of the ENCI-Maastricht B.V. quarry, south of Maastricht, and has been dated at 66,1 million years (Vonhof \& Smit, 1996; Dortangs et al., 2002).

The two rib fragments are registered as NHMM 1998141-44A and -B, respectively. Because portions of the carcass have become severely disarticulated by scavenging sharks prior to final burial (Dortangs et al., 2002), the original position of the rib fragment could not be established with certainty. Nonetheless, numerous positions can be ruled out with certainty, either because these positions are already occupied by preserved, articulated ribs, or because of the circumference of the specimen, or its axial curvature.

In Fig. 1, a partially reconstructed silhouette of the skeleton of $P$. saturator in left and right lateral view, the ribs which have been preserved in articulation are filled in black; the rib positions which are unlikely to have accommodated NHMM 1998141-44 because of reconstructed size or curvature are filled in grey. By elimination, a provenance near the distal dorsal or distal dorsoventral part of the vertebral column appears most likely. None of the other ribs show features similar to the ones described here in NHMM 1998141-44.

\section{Description}

The rib fragment (Fig. 2) is $146 \mathrm{~mm}$ long and $17 \mathrm{~mm}$ wide. Two conspicuous bumps can be observed on the internal (i.e. concave) surface of the rib. Both bumps are raised $3 \mathrm{~mm}$ over the bone surface. On NHMM 1998141-44A the bump measures approximately $15 \times 8 \mathrm{~mm}$; the bump on $-44 \mathrm{~B}$ is slightly larger with $11 \times 16 \mathrm{~mm}$. The bone surface pattern does not appear highly affected, since the faint longitudinal 'striping' on the bone surface continues rather uninterruptedly over the bumps.

The fragment is broken lengthwise about $15 \mathrm{~mm}$ under the two bumps, exposing the internal, spongeous bone structure. No irregularities could be observed there. The oblique fracture between the two

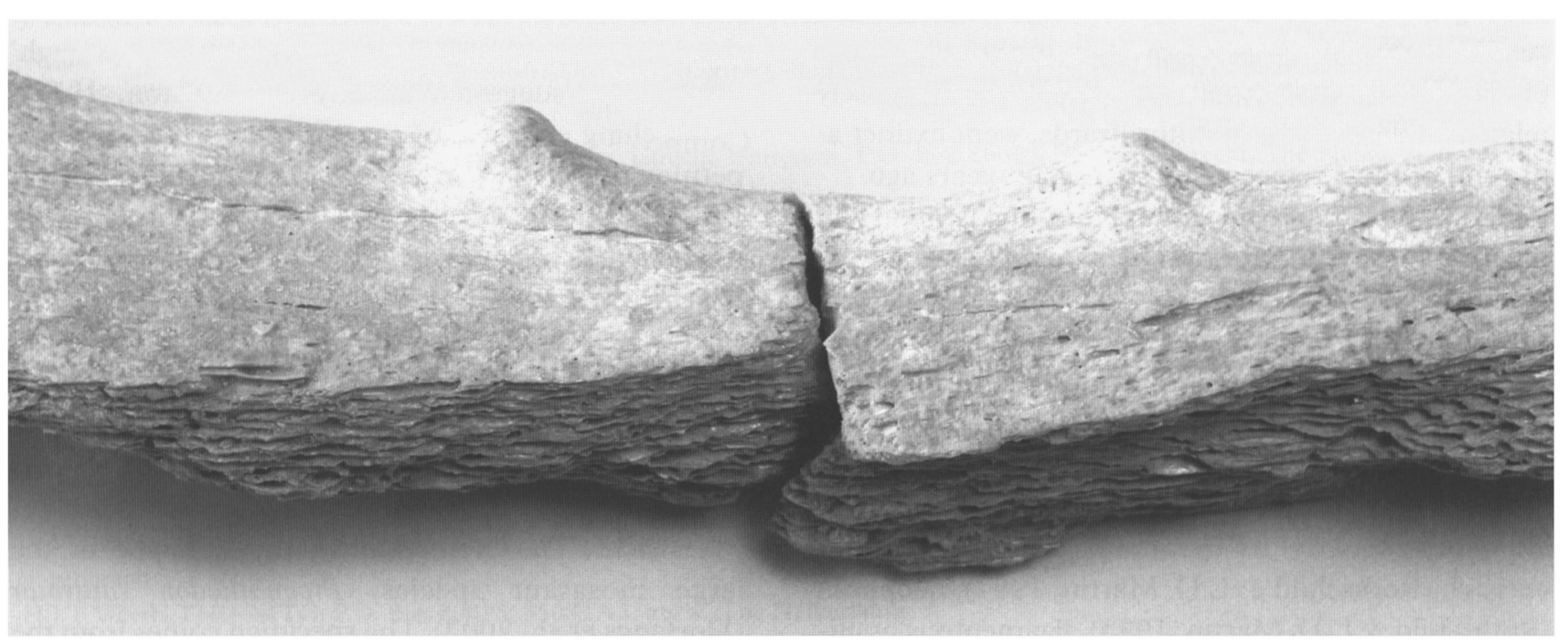

Fig. 2. Pathologies on rib of Prognathodon saturator (NHMM 1998141-44). 
bumps (only 16 and $10 \mathrm{~mm}$ from the centre of bumps $\mathrm{A}$ and $\mathrm{B}$, respectively) does not show any abnormal features either.

X-ray photographs (Fig. 3) reveal a similar pattern: the bone structure underneath the original bone surface appears unaffected, except in the immediate proximity of the bump. In the bumps, a surface cleft may be seen, which trends from the top of the bump down to slightly below the original bone surface, penetrating the original cortex for at least one $\mathrm{mm}$. Additional CT-scans enabled the construction of a better view of the surface cleft, but this yielded no additional information. The surface cleft is just over one $\mathrm{mm}$ wide and appears as a radiolucent line (reduced X-ray attenuation) in the photographs. It could be possible that the cleft continues a bit deeper into the cortex, but this is not visualized because of a density 'artefact': there has to be a variation of 30 to $35 \%$ in bone density for it to be visualized (Resnick 2002).

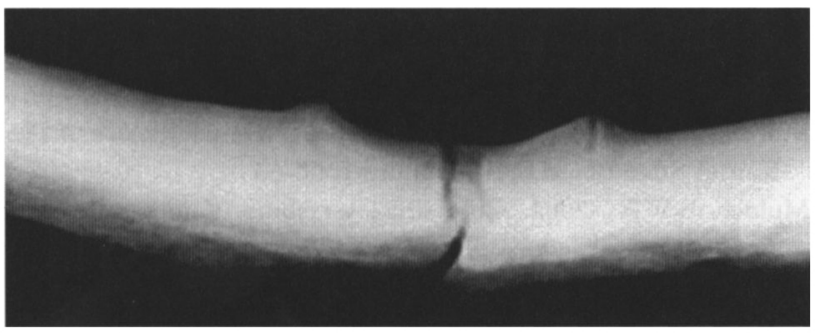

Fig. 3. X-ray of rib of Prognathodon saturator (NHMM 1998141-44).

\section{Interpretation}

We do not consider the features described above to be part of normal mosasaur anatomy. Muscle attachment scars of this size and type are unknown to us, which was confirmed by additional inquiries among other mosasaur workers (pers. comm. E.L. Nicholls, J.E. Martin, E.W.A. Mulder). Additionally, if the features were indeed part of regular anatomy, for reasons of symmetry one could expect similar features on the opposite side. Because the greater part of the ribs of the specimen appears to have been preserved, and no mirror equivalent was found, we consider the 'bumps' to be abnormal, pathologic features, either the result of disease or trauma.

A swelling or 'bump' on bone is known as a 'callus' or 'periosteal bone apposition'. A callus can form as a result of trauma or disease. Usually, a callus is deposited by the periost, the tissue on the bone surface. Callus formation may be induced by various agents, such as infection, cancer, irritation of the periost as a result of stress, fracture or other injury, or by vitaminD-deficiency (a condition known as osteomalacia; see Rothschild (1988) and references therein).
Infection and cancer both significantly affect the underlying bone structure in addition to forming a callus. In infected bone, the original bone structure underneath the callus is profoundly altered. Additionally, the development of a pus drain could be expected. Bone cancer (tumour development, osteomas) would have resulted in the formation of irregular trabeculae (e.g. Rothschild et al., 1999). Osteomas have been previously described in mosasaurs by Rothschild \& Martin (1993), but none of the features discussed above are observed in the specimen described here.

We consider osteomalacia an unlikely explanation for the feature either. Callus formation linked to osteomalacia is usually restricted to the proximal femur and pelvic region (Resnick, 2002), and the formation of irregular trabeculae and a so-called Looser line on the radiographs would be expected here as well.

The most likely explanation, supported by the radiographic appearance and by elimination of the other explanations listed above, would be that the callus formation was triggered by some kind of fracture. Callus formation with a wide, radiolucent surface cleft is typical of stress fractures (Rothschild, 1988; Resnick, 2002). Stress fractures are known to develop in places with continuous or repetitive high stresses, e.g. as in phalanges of ceratopsian dinosaurs, in the hindlimbs of race horses (Rothschild, 1988), but are also commonly seen in, for example, the toe bones of ballet dancers. However, at the first sight, the internal surface of a rib might be a rather unlikely place for the development of stress (fatigue) fractures, since mosasaurs mainly propelled themselves using their powerful tail (Massare, 1997; Mulder, 2001). Only a few reports of stress fractures in human ribs exist (e.g. Bojanic \& Desnica, 1998 and references therein; Resnick, 2002), and all these occurrences are linked to continuous and repetitive heavy exercise.

Two small fissures, not unlike a stress fracture, but as a result of a localised trauma, e.g. a (repeated) attack or perhaps an unfortunate collision with an obstacle while rounding a curve appears a likely explanation. When the animal was hit, the internal (concave) side of the rib would be extended (stress), resulting in small fissures (i.e. fractures not fully extending through the entire rib). Callus formation would soon follow. Since the ribcage is constantly in motion, it would take quite some time for the callus to heal, possibly explaining the width of the surface cleft. 


\section{Discussion}

Although bone fractures in mosasaurs have been described before, to our knowledge no fractures resulting in calluses of this type have so far been reported. Descriptions of fractures in mosasaur bones invariably deal with full, healed fractures, characterised by considerable periosteal bone growth, which reconnects the (often poorly re-aligned) fracture.

Mosasaurs such as $P$. saturator, occupying the top predator niche in the type Maastrichtian marine ecosystem, probably had no natural enemies other than large congeners. Bone fractures are not uncommon in mosasaurs, and certainly a percentage of these fractures might be attributable to intraspecific agonistic behaviour (e.g. Bell \& Martin, 1995). This circumstantial evidence also supports interpreting the pathology described here to have developed as a result of an encounter with another mosasaur.

\section{Acknowledgements}

Many thanks to Hans H.G. Peeters (NHMM) for preparation of the specimen. Elizabeth Nicholls, James Martin, Eric Mulder and Mike Everhart provided helpful comments. Many thanks to reviewers L. vd Hoek Ostende and C. van Oosterhout for helpful feedback.

\section{References}

Bell, G.L., Jr., 1997. Mosasauridae. Introduction. In: Callaway, J.M. \& Nicholls, E.L. (eds): Ancient Marine Reptiles. Academic Press (New York/London): 281-292.

Bell, G.L., Jr. \& Martin, J.E., 1995. Direct evidence of aggressive intraspecific competition in Mosasaurus conodon (Mosasauridae: Squamata). Journal of Vertebrate Paleontology 15(suppl. to 3): 18A.

Bojanic, I. \& Desnica, N., 1998. Stress Fracture of the Sixth Rib in an Elite Athlete. Croatian Medical Journal 39: 458-460.

Dortangs, R.W., Schulp, A.S., Mulder, E.W.A., Jagt, J.W.M., Peeters, H.H.G. \& De Graaf, D.Th., 2002. A large new mosasaur from the Upper Cretaceous of The Netherlands. Netherlands Journal of Geosciences / Geologie en Mijnbouw 81: 1-8.

Gaudry, A., 1890. Les enchaînements du monde animal dans les temps géologiques: fossiles secondaires. Librairie F. Savy (Paris): 323 pp.

Martin, J.E. \& Bell, G.L., Jr., 1995. Abnormal caudal vertebrae of Mosasauridae from Late Cretaceous marine deposits of South Dakota. Proceedings of the South Dakota Academy of Science 74: 23-27.

Martin, L.D. \& Rothschild, B.M. 1989. Paleopathology and diving mosasaurs: American Scientist 77: 460-467.

Massare, J.A., 1997. Faunas, behaviour, and evolution. Introduction. In: Callaway, J.M. \& Nicholls, E.L. (eds): Ancient Marine Reptiles. Academic Press (New York/London): 401-421.

Mudge, B.F., 1878. Geology of Kansas. Biennial Report of the Kansas State Board of Agriculture 1:60-63.

Mulder, E.W.A., 2001. Co-ossified vertebrae of mosasaurs and cetaceans: implications for the mode of locomotion of extinct marine reptiles. Paleobiology 27: 724-734.

Resnick, D. 2002. Diagnosis of Bone and Joint Disorders (3rd edition). W.B. Saunders (Philadelphia): $5472 \mathrm{pp}$.

Rothschild, B.M., 1988. Stress fracture in a ceratopsian phalanx. Journal of Paleontology 62: 302-303.

Rothschild, B.M. \& Martin, L.D., 1987. Avascular Necrosis: Occurrence in Diving Cretaceous Mosasaurs. Science 236: 75-77.

Rothschild, B.M. \& Martin, L.D., 1993. Paleopathology: Disease in the Fossil Record. CRC Press (London): $386 \mathrm{pp}$.

Rothschild, B.M., Witzke, B.J. \& Hershkovitz, I., 1999. Metastatic cancer in the Jurassic. The Lancet 354: 398.

Vonhof, H.B. \& Smit, J., 1996. Strontium-isotope stratigraphy of the type Maastrichtian and the Cretaceous/Tertiary boundary in the Maastricht area (SE Netherlands). In: Brinkhuis, H. \& Smit, J. (eds): The Geulhemmerberg Cretaceous/Tertiary boundary section (Maastrichtian type area, SE Netherlands). Geologie en Mijnbouw 75: 275-282.

Williston, S.W., 1914. Water reptiles of the past and present. Chicago University Press (Chicago): $251 \mathrm{pp}$. 